\title{
Introgression potential between safflower (Carthamus tinctorius) and wild relatives of the genus Carthamus
}

\author{
Marion Mayerhofer ${ }^{1}$, Reinhold Mayerhofer', Deborah Topinka², Jed Christianson', Allen G Good ${ }^{1 *}$
}

\begin{abstract}
Background: Safflower, Carthamus tinctorius, is a thistle that is grown commercially for the production of oil and birdseed and recently, as a host for the production of transgenic pharmaceutical proteins. C. tinctorius can cross with a number of its wild relatives, creating the possibility of gene flow from safflower to weedy species. In this study we looked at the introgression potential between different members of the genus Carthamus, measured the fitness of the parents versus the F1 hybrids, followed the segregation of a specific transgene in the progeny and tried to identify traits important for adaptation to different environments.

Results: Safflower hybridized and produced viable offspring with members of the section Carthamus and species with chromosome numbers of $n=10$ and $n=22$, but not with $n=32$. The T-DNA construct of a transgenic $C$. tinctorius line was passed on to the F1 progeny in a Mendelian fashion, except in one specific cross, where it was deleted at a frequency of approximately $21 \%$. Analyzing fitness and key morphological traits like colored seeds, shattering seed heads and the presence of a pappus, we found no evidence of hybrid vigour or increased weediness in the F1 hybrids of commercial safflower and its wild relatives.
\end{abstract}

Conclusion: Our results suggest that hybridization between commercial safflower and its wild relatives, while feasible in most cases we studied, does not generate progeny with higher propensity for weediness.

\section{Background}

The genus Carthamus is a diverse group of plants within the Asteraceae and is of interest due to the commercial growth of one member, C. tinctorius (safflower) as well as for its potential as a model system to examine the introgression of agronomic and weedy traits across species boundaries and to study the invasiveness of wild relatives of a crop. Safflower is grown in several countries as an oilseed crop and for birdseed and is being evaluated as a crop platform for molecular farming [1]. The different species of Carthamus have been classified into several different grouping systems by different taxonomists. Estilai and Knowles [2] originally placed 13 species in the genus Carthamus into five sections, based on chromosome numbers. Lopez-Gonzalez [3] rearranged the 15 species that he identified into three

\footnotetext{
* Correspondence: allen.good@ualberta.ca

'Department of Biological Sciences, University of Alberta, Edmonton, $A B$, Canada, T6G 2E9

Full list of author information is available at the end of the article
}

sections (Carthamus, Odonthagnathis and Atractylis), to match the understanding of the relationships between the species and their chromosome numbers. In the scheme proposed by Vilatersana et al. [4], the section Carthamus contains the species with 12 sets of chromosomes including C. tinctorius, C. palaestinus and C. oxyacanthus. The section Atractylis $(\mathrm{n}=10,11,22,32)$ contains all other species in the genus including the noxious weeds C. lanatus $(\mathrm{n}=22)$ and C. leucocaulos (n $=10$ ). There are still some species with uncertain placement within the groups, such as C. nitidus [5]. In this report, we have chosen to use the classification system of Lopez-Gonzalez. Elucidating species relationships within Carthamus has been challenging. There are low levels of genetic variation despite clear morphological differences between species $[4,6]$. Random amplified polymorphic DNA markers [RAPDs; 4] and conserved, intron-spanning PCR markers [7] have been utilized to address species relationships. Recently, because of low reproducibility of RAPD marker results [8] and conflict
C Biomed Central

(c) 2011 Mayerhofer et al; licensee BioMed Central Ltd. This is an Open Access article distributed under the terms of the Creative Commons Attribution License (http://creativecommons.org/licenses/by/2.0), which permits unrestricted use, distribution, and reproduction in any medium, provided the original work is properly cited. 
between published data sets, we have utilized microsatellite markers to analyze species relationships [6].

We have been using the genus Carthamus as a model system to study the introgression of traits across species boundaries and the extent to which these traits provide adaptive benefits. Several species of weedy relatives are growing in the same areas as the commercial crops and have the potential to cross and produce fertile offspring with safflower. These include C. lanatus (woolly distaff thistle, saffron thistle), C. leucocaulos (glaucous star thistle, white-stem/yellow distaff thistle), and C. oxyacanthus (jewelled distaff thistle, wild safflower). The genus is native to the Middle East; however, its distribution has expanded into many countries across the world including Australia and North America [9]. Both $C$. lanatus and $C$. leucocaulos are considered noxious weeds in California and Australia. In Australia, C. lanatus has become a weed after it was introduced from the Mediterranean. It has spread throughout the continent [10] and is currently considered the most economically damaging thistle species in New South Wales [11]. There are other thistle species within the family Asteraceae and some of them are noxious weeds, including spotted knapweed (Centaurea maculosa), diffuse knapweed (Centaurea diffusa) and star thistle (Centaurea solstitialis). These species are highly invasive, particularly in drier Prairie climates. In Canada, knapweed is now recognized as a major invasive weed, causing significant damage to a number of Prairie agroecosystems [12].

Hybridization of safflower with sympatric wild relatives has probably played a significant role in the evolution of Carthamus and cultivated safflower in the Mediterranean [13-15]. For example, the hexaploid noxious weeds $C$. creticus and C. turkestanicus are allopolyploids resulting from the hybridization of a tetraploid ancestor (C. lanatus) with a diploid progenitor lineage (C. leucocaulos and C. glaucus, respectively) [15]. The fact that these species intercross and that some of the relatives are weedy, leads to concerns about transgene escape from cultivated $C$. tinctorius plants and the potential for commercial safflower to cross with its weedy relatives and become feral or "de-domesticated".

The evolution of agricultural weeds from wild species is a recurring pattern in the history of agriculture, with plants from numerous families evolving weedy genotypes that thrive in cultivated areas [16]. This is not surprising, given the evidence that 12 of the 13 most important food crops hybridize with at least one wild relative within their range [Reviewed in 17]. Typically, during the development of crop plants a number of traits are commonly selected for, including high germination rates, yield, oil profile, earliness and developmental consistency. Similarly, when a wild species evolves into an agricultural weed, a number of important adaptations occur, including rapid seedling growth, high competitive ability and increases in both seed output and dispersal [18]. These adaptations are relevant for several reasons. First, these traits are encoded by multiple independent genes and the evolution of similar traits in different species is of interest from a comparative genetics viewpoint [19]. Second, the adaptations often result from the transfer of crop genes that provide specific life history traits for the hybrid to become a noxious weed. A particularly clear example of this has been the transfer of transgenes that encode herbicide resistance to create weeds with herbicide tolerance [20,21].

In addition to concerns about transgene escape there are now speculations that certain traits will allow invasive species to capitalize on different elements of global climate change [22].

In this paper, we describe which members of the Carthamus tribe can hybridize with cultivated safflower, determine whether the hybrid plants have a higher fitness than the $C$. tinctorius parent and look at the segregation of a herbicide resistance transgene in an interspecific cross. Finally, we analyze traits potentially important for adaptation to specific biotic environments.

\section{Results}

\section{Crossing success and fitness of hybrids}

Table 1 outlines the total number of seeds harvested and the success rate (\# seeds produced/\# crosses attempted $\times 100)$ of each cross. The success rate of controlled crosses between a transgenic C. tinctorius (Centennial) and other Carthamus species varied from $0 \%$ to $67 \%$, compared to the C. tinctorius/C. tinctorius control cross of $40 \%$. We are aware that some of the Carthamus lines obtained from the USDA might be fairly inbred and therefore may have given low seed set due to inbreeding depression.

Crosses with species in the section Carthamus $(\mathrm{n}=$ 12; C. oxyacanthus and C. palaestinus) generally worked, regardless of whether $C$. tinctorius was the male or female parent. Crosses worked equally well with $C$. palaestinus as either the female $(38 \%)$ or the male $(31 \%)$ parent. Two different accessions of C. oxyacanthus (PI 426427, PI 426477) had a low success rate as the female parents $(2 \%$ and $14 \%)$ with somewhat higher values as the male parents (15\% and $23 \%)$. A nontransgenic variety of C. tinctorius (Centennial) was also crossed with two other accessions of C. oxyacanthus. These crosses worked well with C. oxyacanthus as female parent (56\% and $30 \%)$ and a bit less efficient as the male parent $(21 \%$ and $42 \%$; data not shown).

Crosses between species of the section Odonthagnathis (n = 10; C. leucocaulos and C. glaucus) and C. tinctorius were relatively successful, ranging from $14 \%$ 
Table 1 Success of crosses between $C$. tinctorius and relatives of the Carthamus-Carduncellus complex

\begin{tabular}{|c|c|c|c|c|c|c|c|c|}
\hline \multirow[b]{2}{*}{ Female parent } & \multicolumn{8}{|c|}{ Male parent } \\
\hline & C. oxyacanthus ${ }^{c}$ & C. palaestinus & C. leucocaulos & C. glaucus & C. lanatus & C. turkestanicus & C. creticus & C. tinctorius \\
\hline C. oxyacanthus $(n=12)^{c}$ & $6 \%(6)$ & & & & & & & $2 / 14 \%(32)$ \\
\hline C. palaestinus $(n=12)$ & & $15 \%(9)$ & & & & & & $38 \%(84)$ \\
\hline C. leucocaulos $(\mathrm{n}=10)$ & & & $68 \%(28)$ & & & & & $67 \%(92)^{a}$ \\
\hline C. glaucus $(n=10)$ & & & & $16 \%(6)$ & & & & $18 \%(40)$ \\
\hline C. lanatus $(n=22)$ & & & & & $49 \%(28)$ & & & $17 \%(26)^{a}$ \\
\hline C. turkestanicus $(n=32)$ & & & & & & $54 \%(58)$ & & $0.3 \%(1)^{b}$ \\
\hline C. creticus $(\mathrm{n}=32)$ & & & & & & & $55 \%(22)$ & $2 \%(3)$ \\
\hline C. tinctorius $(n=12)$ & $15 / 23 \%(82)$ & $31 \%(86)$ & $14 \%(23)^{a}$ & $41 \%(67)$ & $29 \%(55)^{a}$ & $0 \%$ & $0 \%$ & $40 \%(131)$ \\
\hline
\end{tabular}

Calculation of success rate: (\# seeds produced/\# crosses attempted) $\times 100$. Number in brackets is the number of seeds harvested.

a sterile F1 plants

b no F1 plants

c C. oxyacanthus genotypes PI 426427/PI 426477

to $67 \%$ success rate. The cross with C. glaucus produced fertile F1 plants; however, the cross with $C$. leucocaulos resulted in sterile offspring. Our recent data and similar findings by other laboratories have raised doubts about the identity of the C. glaucus samples that are being distributed by USDA Pullman, WA, i.e. these seeds might in fact not be from C. glaucus but from a species with $\mathrm{n}$ $=12$.

For the section Atractylis ( $\mathrm{n}=22,32 ; C$. lanatus, $C$. turkestanicus, $C$. creticus), the cross between $C$. lanatus $(\mathrm{n}=22)$ and C. tinctorius worked well with C. lanatus as male parent $(29 \%)$, with a lower success rate as female parent (17\%). However, all F1 plants from this cross were sterile.

For C. turkestanicus, two different genotypes were used (PI 426180, PI 426426). Only one seed was harvested, giving a success rate of $0.3 \%$. We did not determine whether this seed was truly a hybrid, would germinate and produced viable F1 plants.

C. creticus as female parent gave a $2 \%$ success rate, and $0 \%$ as male parent, therefore it was assumed that crosses between these species were unlikely to work. In summary, crosses with members of the section Atractylis were successful for C. lanatus $(\mathrm{n}=22)$ but failed for C. creticus and C. turkestanicus (both $\mathrm{n}=32$ ).
A number of seeds from all crosses, except C. creticus and $C$. turkestanicus, were imbibed to determine the germination rates and to produce F1 plants for further analysis (Table 2 and 3). In total $197 \mathrm{~F} 1$ plants were generated and all, except two self-pollinated individuals, were true hybrids as verified by species-specific microsatellite markers and antibody based test strips. The hybrid plants were subsequently selfed for the generation and analysis of F2 seeds (Table 3).

While there are a number of ways of calculating parental and F1 fitness, our calculation of fitness was based solely on the total seed set per plant, given as a fraction of the seed set of the commercial cultivar Centennial (Table 2). However, we note that some of the Carthamus lines are likely to be fairly inbred, due to repeated selfing and seed collection, which occurs as a result of the way the USDA maintains its lines. Thus, some selfs may have given low seed set due to inbreeding depression, whereas outcrossing relieves this, resulting in higher seed set.

Parental fitness varied from 0.05 (for one C. oxyacanthus genotype) to 13.41 (for C. leucocaulos), compared to the Centennial parental fitness (1.00). The F1 fitness was zero for C. lanatus and C. leucocaulos as all of the self-pollinated F1 plants (11 and 18 plants,

Table 2 Fitness and transgene deletion

\begin{tabular}{lcccc}
\hline Species & Parental fitness & F1 fitness & F1 germination rate (\%) & Deletion of transgene in F1s \\
\hline C. glaucus $(n=10)$ & 0.46 & 1.22 & 75 & $21 \%(15 / 72)$ \\
C. leucocaulos $(n=10)$ & 13.41 & 0 & 80 & $0 \%(0 / 62)$ \\
C. oxyacanthus $(n=12)^{a}$ & $1.27 / 0.05$ & $1.06 / 1.21$ & $32 / 36$ & $0 \%(0 / 34)$ \\
C. palaestinus $(n=12)$ & 2.21 & 1.60 & 90 & $0 \%(0 / 9)$ \\
C. tinctorius $(n=12)$ & 1.00 & - & - & $0 \%(0 / 67)$ \\
C. lanatus $(n=22)$ & 6.51 & 0 & 33 & $0 \%(0 / 18)$ \\
\hline
\end{tabular}

Calculation of fitness: Parental fitness = (\# parental seed/\# Centennial seed), F1 Fitness = (\# F2 seed/\# Centennial seed).

${ }^{a}$ C. oxyacanthus genotypes PI 426427/PI 426477 
Table 3 Domestication and ferality characteristics of F1 hybrids between $C$. tinctorius and wild relatives

\begin{tabular}{|c|c|c|c|c|c|c|c|}
\hline \multirow[b]{2}{*}{ Plant stage } & \multirow[b]{2}{*}{ Trait } & \multicolumn{6}{|c|}{ F1 hybrids with C. tinctorius } \\
\hline & & C. oxy. $(27)^{a}$ & C. oxy. $(77)^{b}$ & C. pal. & C. leuc. & C. glauc. & C. Ian. \\
\hline \multirow[t]{6}{*}{ Seed } & Pappus (TQ/Tơ) & $\mathrm{No} / \mathrm{No}$ & $\mathrm{No} / \mathrm{No}$ & No/Some & No/Yes & $\mathrm{No} / \mathrm{No}$ & No/Yes \\
\hline & Seed color (TQ/Tơ) & W-T/St-W & W-T/St-W & C-B/W-C & $W-B / B$ & C-T/W-C & $\mathrm{T}-\mathrm{B} / \mathrm{T}-\mathrm{B}$ \\
\hline & mg/seed (To) & $38.7 \pm 10.9$ & $38.7 \pm 7.9$ & $53.3 \pm 4.8$ & $31.0 \pm 6.7$ & $47.3 \pm 5.3$ & $21.1 \pm 4.7$ \\
\hline & mg/seed (Tơ) & $13.0 \pm 0.0$ & $11.7 \pm 2.0$ & $51.1 \pm 17.1$ & $11.6 \pm 1.1$ & $36.3 \pm 3.8$ & $17.8 \pm 1.0$ \\
\hline & Seed weight (\% Centennial, TQ/Tơ) & $71.4 \% / 24.0 \%$ & $71.4 \% / 21.6 \%$ & $98.3 \% / 94.3 \%$ & $57.2 \% 21.4 \%$ & $87.3 \% / 67.0 \%$ & $38.9 \% / 32.8 \%$ \\
\hline & Germination rate & $32 \%$ & $36 \%$ & $90 \%$ & $80 \%$ & $75 \%$ & $33 \%$ \\
\hline Rosette & Number of spines & $29.0 \pm 4.6$ & $31.5 \pm 8.4$ & $25.7 \pm 7.7$ & $102.6 \pm 17.3$ & $21.8 \pm 3.4$ & $104.7 \pm 10.8$ \\
\hline Bolting & Rosette period (days) & $22.7 \pm 2.0$ & $23.1 \pm 0.6$ & $19.4 \pm 3.7$ & $28.9 \pm 2.0$ & $20.0 \pm 0.9$ & $36.3 \pm 1.2$ \\
\hline \multirow[t]{3}{*}{ Inflorescence } & Days to flowering & $57.4 \pm 2.4$ & $61.5 \pm 1.9$ & $60.8 \pm 3.9$ & $62.9 \pm 3.5$ & $61.1 \pm 1.5$ & $71.7 \pm 0.6$ \\
\hline & Days of flowering & $66.6 \pm 7.5$ & $72.1 \pm 17.7$ & $<48.1$ & $96.6 \pm 9.6$ & $45.2 \pm 10.2$ & $76.7 \pm 11.1$ \\
\hline & Number of branches & $10.1 \pm 1.2$ & $12.5 \pm 1.9$ & $7.0 \pm 1.5$ & $10.3 \pm 1.7$ & $10.0 \pm 2.1$ & $6.7 \pm 1.2$ \\
\hline \multirow[t]{2}{*}{ Mature head } & Shattering & low to high & low to high & No & $\mathrm{n} / \mathrm{a}$ & Some & $\mathrm{n} / \mathrm{a}$ \\
\hline & Flower heads/plant & $41.7 \pm 5.1$ & $41.8 \pm 8.2$ & $9.7 \pm 1.4$ & $79.0 \pm 8.7$ & $11.3 \pm 4.2$ & $42.3 \pm 12.3$ \\
\hline \multirow[t]{3}{*}{ F2 seed } & F2 seeds/plant (\#) & $179 \pm 88$ & $205 \pm 141$ & $271 \pm 64$ & 0 & $205 \pm 47$ & 0 \\
\hline & F2 seed/plant (g) & $6.2 \pm 2.8$ & $6.8 \pm 4.5$ & $12.5 \pm 2.5$ & 0 & $10.5 \pm 2.1$ & 0 \\
\hline & F2 mg/seed & $35.6 \pm 3.7$ & $34.5 \pm 4.5$ & $47.4 \pm 9.0$ & $\mathrm{n} / \mathrm{a}$ & $51.6 \pm 5.6$ & $\mathrm{n} / \mathrm{a}$ \\
\hline
\end{tabular}

Phenotypes were obtained from three to ten F1 hybrids from each cross.

${ }^{\text {a }}$ C. oxyacanthus genotype PI $426427,{ }^{b}$ C. oxyacanthus genotype PI 426477, TO: $C$. tinctorius was the female parent, Tơ: $C$. tinctorius was the male parent. Seed color: (W) white, (C) cream, (T) tan, (B) brown, (St) brown/brown striped. Rosette spine number: Maximum number of spines per leaf. Shattering: (low to high) variable frequency of shattering.

respectively) had a very low amount of pollen and none of them produced any seed.

\section{Domestication and weedy characteristics of $C$. tinctorius and the wild relatives}

After analyzing the key descriptors for safflower [23], we developed a list of traits that could potentially be associated with domestication or weediness and analyzed them in the parental species (Table 4) and the F1 hybrids (Table 3 ). These included seed weight, seed color, presence of a pappus, number of seeds produced, time at rosette stage, spininess, time to flowering, time of flowering and shattering versus non-shattering heads. Three key morphological traits that may be associated with weediness are colored seeds, shattering seed heads and the presence of a pappus. Carthamus lanatus, $C$. leucocaulos, C. turkestanicus and C. creticus all have a pappus on their seeds and are shattering, and most of the wild species have seeds that are tan, brown or brown striped, all of which should help in seed dispersal and in reducing seed predation. Additionally, most of the wild species studied had much higher numbers of seeds per plant.

Other traits that may be related to weediness or invasiveness are a longer time at the rosette stage and to the start of flowering, as well as spininess. Shoot elongation is delayed for the weedy relatives and their time at the rosette stage was 1.8 to 6.9 times that of Centennial. For the F1 plants this was 1.6 to 2.9 times and it always fell between the two parents.

Time to flowering differed substantially between the species analyzed, with C. leucocaulos and C. lanatus showing the longest time. The values for the F1s fell between the two means of their parents.

There was a wide range of the number of selfed seeds per plant for the parental species, ranging from a few to over two thousand, although some individual plants did not produce any seeds at all. The wild relatives, particularly C. lanatus and C. leucocaulos, had many more seeds than Centennial. Having many smaller-sized seeds is probably a strategy used by these weeds to increase the dispersal and the probability that a viable seed will find a suitable environment. The two genotypes of $C$. oxyacanthus (PI 426427 and PI 426477) produced quite different amounts of seed (215 vs. 8) which may reflect some inherent self-incompatibility systems [24]. The seed set of the F1 plants also varied between the different crosses. However, the biggest variation was again seen between the progeny of the C. oxyacanthus $-C$. tinctorius cross. 
Table 4 Domestication and ferality characteristics of parental species within the Carthamus family

\begin{tabular}{|c|c|c|c|c|c|c|c|c|c|}
\hline \multirow[b]{2}{*}{ Plant stage } & \multirow[b]{2}{*}{ Trait } & \multicolumn{8}{|c|}{ Parental species } \\
\hline & & C. tinct. & ${ }^{a} \mathrm{C}$. oxy. & C. pal. & C. leuc. & C. glauc. & C. Ian. & ${ }^{b} \mathrm{C}$. turk. & C. cret. \\
\hline \multirow[t]{5}{*}{ Seed } & Pappus & No & No & Some & Yes & Some & Yes & Yes & Yes \\
\hline & Seed color & W & St & W & B & W-T & T-B & B & B \\
\hline & $\mathrm{mg} / \mathrm{seed}$ & $51.4 \pm 4.5$ & $9.9 / 13.1$ & $38.6 \pm 5.6$ & $9.1 \pm 0.3$ & $44.4 \pm 4.4$ & $32.5 \pm 3.7$ & $44.5 / 49.8$ & $25.8 \pm 2.1$ \\
\hline & Germination rate & $95 \%$ & $50 \% / 75 \%$ & $92 \%$ & $100 \%$ & $44 \%$ & $100 \%$ & $39 \% / 100 \%$ & $72 \%$ \\
\hline & Seeds per plant & $169 \pm 55$ & $215 / 8$ & $373 \pm 163$ & $\begin{array}{l}2267 \pm \\
306\end{array}$ & $77 \pm 43$ & $\begin{array}{c}1100 \pm \\
100\end{array}$ & $860 / 543$ & $753 \pm 46$ \\
\hline Cotyledon & Cotyledon size & $55.2 / 21.7$ & $\begin{array}{c}51.5 / 8.555 .6 / \\
11.5\end{array}$ & $51.6 / 21.6$ & $34.5 / 14.1$ & $51.0 / 20.9$ & 70.8/29.7 & $\begin{array}{c}55.1 / 27.959 .2 / \\
28.8\end{array}$ & $61.4 / 21.9$ \\
\hline \multirow[t]{4}{*}{ Rosette } & Leaf blade shape & oblanceolate & oblanceolate & oblanceolate & bipinnatifid & oblanceolate & pinnatifid & bipinnatifid & bipinnatifid \\
\hline & Number of leaves & $3.9 \pm 0.6$ & $12.5 / 15.7$ & $11.0 \pm 6.9$ & $51.8 \pm 1.8$ & $8.8 \pm 1.6$ & $47.0 \pm 5.8$ & $74.0 / 53.8$ & $34.6 \pm 5.7$ \\
\hline & Number of spines & $12.9 \pm 0.9$ & $51.0 / 51.3$ & $47.0 \pm 6.9$ & $300.0 \pm 0.0$ & $42.0 \pm 7.13$ & $\begin{array}{c}460.0 \pm \\
0.0\end{array}$ & $300.0 / 300.0$ & $\begin{array}{c}316.0 \pm \\
43.4\end{array}$ \\
\hline & Spine location & 1 & 4 & 3 & 4 & 2 & 4 & 4 & 4 \\
\hline \multirow[t]{4}{*}{ Bolting } & $\begin{array}{l}\text { Rosette period } \\
\text { (days) }\end{array}$ & $12.4 \pm 1.5$ & $30.0 / 44.3$ & $28.2 \pm 6.2$ & $85.0 \pm 1.4$ & $22.0 \pm 1.1$ & $74.6 \pm 2.7$ & $110.0 / 106.2$ & $66.6 \pm 8.1$ \\
\hline & $\begin{array}{l}\text { Number of } \\
\text { branches }\end{array}$ & $5.6 \pm 0.9$ & 11.0/19.3 & $8.0 \pm 2.6$ & $11.3 \pm 1.5$ & $17.3 \pm 1.5$ & $13.0 \pm 3.6$ & $11.0 / 22.3$ & $27.7 \pm 3.5$ \\
\hline & Branch angle & । & 1 & I & $A / I$ & I & S & S & S \\
\hline & Branching position & upper $3 / 5$ & base to apex & upper $3 / 5$ & $\begin{array}{l}\text { base to } \\
\text { apex }\end{array}$ & $\begin{array}{l}\text { base to } \\
\text { apex }\end{array}$ & upper $4 / 5$ & upper $3 / 5$ & upper $3 / 5$ \\
\hline \multirow[t]{3}{*}{ Inflorescence } & Days to flowering & $69.1 \pm 4.0$ & $63.0 / 85.0$ & $75.0 \pm 13.0$ & $\begin{array}{c}153.2 \pm \\
34.6\end{array}$ & $63.2 \pm 1.9$ & $\begin{array}{c}122.8 \pm \\
8.5\end{array}$ & 145.5/139.0 & $98.6 \pm 4.6$ \\
\hline & Days of flowering & $36.3 \pm 10.8$ & $\mathrm{na} / 64.7$ & $64.0 \pm 19.2$ & $99.3 \pm 4.5$ & $97.5 \pm 3.5$ & $\begin{array}{l}54.7 \pm \\
12.7\end{array}$ & 108.3/70.0 & $52.7 \pm 7.0$ \\
\hline & Heads per branch & $5.0 \pm 1.2$ & $38.0 / 16.7$ & $6.3 \pm 4.9$ & $68.3 \pm 19.7$ & $6.7 \pm 2.9$ & $26.0 \pm 1.7$ & 11.0/9.3 & $14.0 \pm 1.7$ \\
\hline New flowers & $\begin{array}{l}\text { Corolla color } \\
\text { (petals) }\end{array}$ & yellow & yellow & yellow & $\begin{array}{l}\text { white- } \\
\text { purple }\end{array}$ & yellow & yellow & light yellow & cream \\
\hline \multirow[t]{2}{*}{ Mature head } & Shattering & No & Some/Some & No & Yes & No & Yes & Yes & Yes \\
\hline & $\begin{array}{l}\text { Flower heads per } \\
\text { plant }\end{array}$ & $9.0 \pm 1.9$ & 215.0/144.0 & $35.0 \pm 19.9$ & $\begin{array}{c}413.3 \pm \\
24.8\end{array}$ & $57.3 \pm 21.7$ & $\begin{array}{c}126.0 \pm \\
42.3\end{array}$ & $50.7 / 70.3$ & $85.7 \pm 9.2$ \\
\hline
\end{tabular}

Phenotypes were obtained from a minimum of five parental individuals.

${ }^{a}$ C. oxyacanthus genotypes PI 426427/PI 426477, b C. turkestanicus genotypes PI 426180/PI426426.

C. tinct.: C. tinctorius, C. oxy.: C. oxyacanthus, C. pal.: C. palaestinus, C.leuc.: C. leucocaulos, C. glauc.: C. glaucus, C. lan.: C. lanatus, C. turk.: C. turkestanicus, C. cret.: C. creticus. Seed color: (W) white, (C) cream, (T) tan, (B) brown, (St) brown/brown striped. Cotyledon size: Length/Width in mm. Rosette spine number: Maximum number of spines per leaf. Rosette spine location: (1) distal $1 / 3$ to $1 / 2,(2)$ distal $1 / 2$ to $2 / 3$, (3) distal $1 / 2$ to all along margins, (4) tip and all along margins. Branch angle: (A) appressed $\left(15^{\circ}\right.$ to $\left.20^{\circ}\right)$, (I) intermediate $\left(20^{\circ}\right.$ to $\left.60^{\circ}\right)$, (S) spreading $\left(60^{\circ}\right.$ to $\left.90^{\circ}\right)$. Heads per branch: Maximum number.

The F1 germination rates of the two C. oxyacanthus accessions and of $C$. lanatus were about a third of $C$. tinctorius, which was almost $100 \%$. They ranged from $32 \%$ to $36 \%$ and were also considerably lower than the germination rates of their weedy parents (50\% to $100 \%)$. For $C$. lanatus, F1 seeds from the cross with C. tinctorius as the male parent had a considerably higher germination rate than from the reciprocal cross (not shown). C. leucocaulos and C. palaestinus parental and F1 seeds germinated at very similar rates $(80 \%$ to $100 \%)$, whereas the C. glaucus F1s did significantly better than their weedy parent ( $75 \%$ vs. $44 \%)$. It should be noted however that fitness measurements on material which has very different histories (inbred for several generations, compared to a commercial cultivar or an F1 hybrid), are extremely difficult to compare, due to possible genetic effects associated with cultivar development, inbreeding or differences in hybrid breakdown in the F2 generation.

The seed weight of the F1 seeds either fell between that of Centennial (the parent with the larger seeds) and the wild relative, or it was lower. F1 seeds were always similar in color, size, shape and seed weight to the female parent of the cross, suggesting some degree of maternal inheritance to these traits (Table 3). The weight of the F2 seeds was between that of the two parents and there was no difference whether Centennial was the female or the male parent.

The weedy species are primarily shattering, which is likely to increase the dispersal rate of the seed. Since $C$. lanatus, C. leucocaulos, C. turkestanicus and C. creticus hybrids did not develop any F2 seed set, we have no data about this trait from these species. In the case of $\mathrm{C}$. 
oxyacanthus, all the selfed F1 plants were shattering at variable degrees, suggesting a dominant trait; however, our data do not allow a more detailed genetic analysis.

Seed color was difficult to evaluate genetically but the weedy species and their F1 hybrids had mostly striped to brown seeds, that are clearly less visible against a soil, crop or grassland background.

The frequent presence of a pappus in C. lanatus, $C$. leucocaulos, C. turkistanicus and C. creticus indicates the value of this trait in these weedy species. We observed a pappus in the F1 seed when the weedy relative was the female parent, but not the reciprocal cross. Again, we could not analyze any F2 seeds for this trait in these crosses. Regardless of the trait measured, the F1 plants usually had a phenotype that was midway between the parents.

\section{Deletion of the transgene in specific F1 hybrids}

The presence of the transgene in the F1 crosses was verified using an antibody strip test as well as T-DNA specific PCR primers, detecting the pat protein and pat gene, respectively. Additionally, the integrity of the left and right T-DNA border/plant DNA junctions were analyzed by PCR using the LB/LGS and RB/RGS primer pairs (Figure 1). We found that, with one exception, all crosses produced F1 offspring carrying the intact transgene. However, when C. tinctorius was crossed with C. glaucus, the pat protein and pat gene were absent in $21 \%$ of the progeny (Table 2). Instead, in those F1 plants the LGS and RGS primers amplified a single band of the same size as in the genomic region of the nontransgenic Centennial control, suggesting a complete deletion of the T-DNA construct. Table 5 shows the PCR and strip test results for four (out of 72 analyzed) F1 individuals, along with two controls plants. Hybrids glauc1 and glauc2 showed a deletion of the T-DNA construct, whereas glauc3 and glauc7 retained it. These patterns were consistent for all of the F1s we analyzed, i.e. the F1s that lacked the pat protein, the pat gene and the left and right T-DNA borders produced a wildtype Centennial band and vice versa. Since we separated the PCR products only by agarose gel electrophoresis, we were unable to determine whether there were any smaller deletions $(<20 \mathrm{bp})$ associated with the excision of the transgene. We did not observe any discernible morphological differences between these F1 plants and the ones carrying the transgene.

\section{Discussion}

\section{Hybrid production}

Safflower is considered one of humanities' oldest crops and has therefore been selected for domestication traits over several centuries [25]. It does have numerous wild relatives and gene transfer through interspecific hybridization may introduce weedy traits into the commercial crop, creating the potential for invasive hybrid populations [26-28]. Alternately, it can also provide an avenue for the transfer of novel traits from specially developed crops to wild populations. In the Old World there are a number of wild relatives that coexist with C. tinctorius, for example C. palaestinus, C. persicus and C. oxyacanthus $[9,25,29,30]$. In the New World, potential recipients of genes from cultivated safflower include four naturalized wild relatives, C. creticus, C. lanatus, C. leucocaulos and C. oxyacanthus. Of these, $C$. oxyacanthus and $C$. creticus have previously been shown to produce viable hybrid offspring with $C$. tinctorius [5]. We have now demonstrated that most of the wild relatives, which have 10 or 12 chromosomes, produce viable and fertile hybrids with C. tinctorius.

A number of hybrids from the different interspecific crosses are currently being advanced by selfing, as well as backcrossing to the wild parents. Monitoring of the fitness of subsequent generations will give us a better idea about the adaptive value of the incorporated crop genes. Also, other effects like hybrid breakdown [31] can be better recognized at later generations.

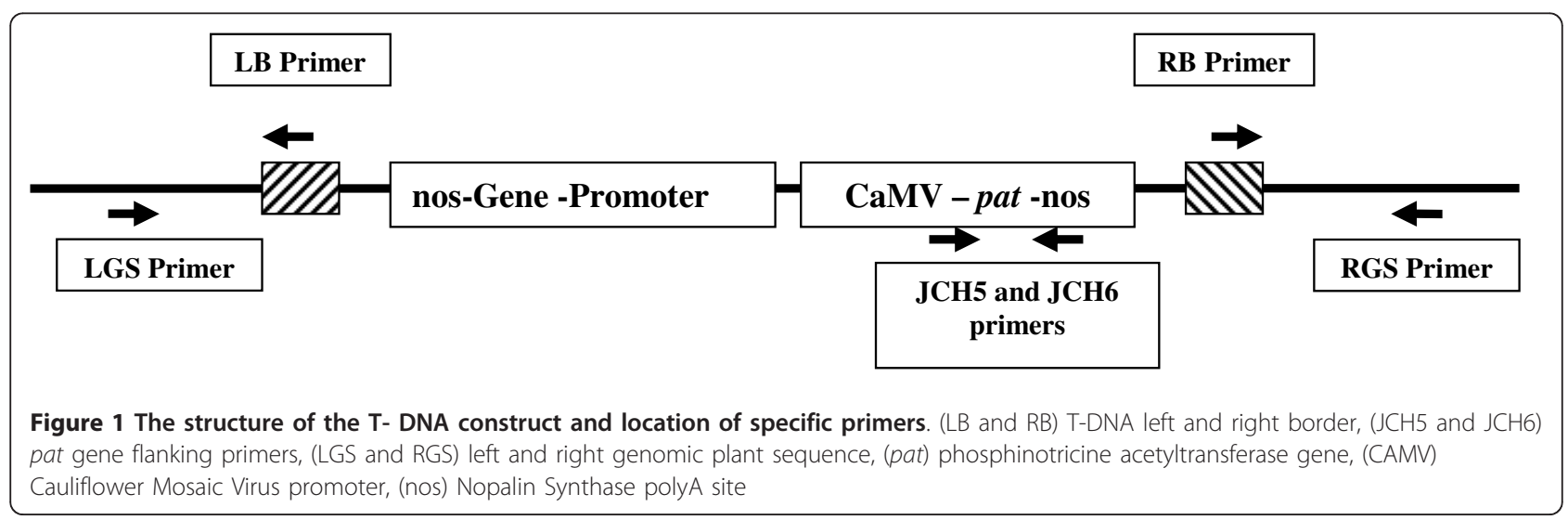


Table 5 PCR and antibody analysis of C. tinctorius. $\times$ C. glaucus F1 plants

\begin{tabular}{|c|c|c|c|c|c|c|}
\hline Control/Cross & Sample Plant & RB/RGS & LB/LGS & JCH5/JCH6 & LGS/RGS & pat Strip Test \\
\hline Non-transgenic Centennial & Cent 10-2-4-1 & - & & - & + & - \\
\hline Transgenic Centennial & T43 & + & + & + & - & + \\
\hline T43 $\times$ glauc $51-5-1$ & glauc 1 & - & - & - & + & - \\
\hline T43 $\times$ glauc $51-5-1$ & glauc 2 & - & - & - & + & - \\
\hline T43 $\times$ glauc $51-5-3$ & glauc 3 & + & + & + & - & + \\
\hline T45 $\times$ glauc $51-5-1$ & glauc 7 & + & + & + & - & + \\
\hline
\end{tabular}

Cent 10-2-4-1: Non-transgenic C. tinctorius Centennial; T43 and T45: Transgenic C. tinctorius Centennial; glauc 51-5-1 and glauc 51-5-3: C. glaucus parent; glauc 1; glauc 1, glauc 2, glauc 3, glauc 7: C. glaucus F1 plants.

\section{Domestic versus weedy traits}

Many of the traits detected in cultivated safflower such as Centennial have clearly been selected for by breeders. These include consistent white seeds, high germination rates, high yield and yield correlates (seed number and seed size), absence of a pappus, non-shattering, erect stature, etc. Therefore, the traits that may provide a selective advantage in an agricultural setting may not be selected for in nature or in an invasive weed. For example, while a high germination rate is valuable from a producer's perspective, delaying germination until a second year might allow a weedy genotype to germinate in a different environment, either in terms of the competitive environment (a different crop) or a different abiotic environment.

Several weedy relatives of $C$. tinctorius have been studied and hybrids between these relatives and safflower have been used to study the inheritance of a number of domestication traits $[32,33]$. The wild and weedy species C. oxyacanthus, C. persicus and C. palaestinus were shown to have seeds that are released by shattering, although in our study $C$. palaestinus was non-shattering. These species are homozygous dominant for the gene $S h$, while cultivated safflower genotypes are homozygous recessive for this locus $(s h)[29,30]$. Another trait that alters seed dispersal in the Asteraceae is the presence of a pappus, a seed appendage for dispersal via water, wind and adherence to animal fur. Most of the seeds of safflower lack a pappus and when it is present, it is less than the length of the achenes. The gene controlling the presence of a pappus in $C$. persicus has been shown to be dominant $\left(P_{-}\right)$, while commercial safflower is homozygous recessive for this locus $(p p)$ [30]. A third trait that has been genetically characterized is the duration of cultivated safflower's rosette stage, which is shortened by a single dominant gene (ro), reducing the maturity time of the crop, which might also affect the invasiveness of a particular genotype [30]. The longer rosette stage of both $C$. persicus and $C$. oxyacanthus helps their seeds to be dispersed in the field after harvest of the cereal crops they often grow among. Domestication traits such as large seed, reduced shattering, lack of pappus and short duration of the rosette stage ensure that the majority of safflower seeds are harvested. Reduced seed dormancy causes the seeds to germinate when planted so they are less likely to persist in the seed bank.

Data obtained from crosses of $C$. tinctorius with other species can be used as an initial indicator to predict the potential for hybridization and subsequent introgression of a gene from a cultivated crop into a weedy population and vice versa. Hybrids between safflower and wild relatives could potentially serve as a source of feral safflower populations but hybridization and introgression would require that both plants be sympatric in their distribution and flower at the same time. Our analysis of some of the traits that make $C$. tinctorius a commercial crop suggests that they are unlikely to provide any selective advantage.

\section{Segregation of a transgene in the hybrids}

The movement of a specific transgene to the offspring was analyzed using a homozygous line with a single $\mathrm{T}$ DNA insert. We observed that in all of the crosses, except one, the transgene acted as a normal Mendelian trait. However, in the C. tinctorius $\times$ C. glaucus cross, the transgene was deleted at a frequency of $21 \%$.

The ultimate fate of a transgene in nature is affected by several factors including its frequency in the population, the probability that the gene will be transferred to the hybrid plant and finally, the selective advantage the gene confers to the new host species [34]. It seems unlikely that transgenes used for the production of Plant Made Pharmaceuticals (PMPs) would improve the viability or survival of feral safflower. In fact the only data we are aware of (McPherson M., unpublished data), suggest that the PMP trait used in these experiments reduces the fitness of the seed. Haygood et al. [35] have shown in their analysis that the likelihood of establishment and rate of spread of a transgene is governed primarily by the strength of selection, as opposed to the migration rate $[35,36]$. 
Several pieces of data now point to the unlikelihood of transgene escape, except when the transgene provides a selective advantage to the hybrid, e.g. herbicide tolerance. First, the outcrossing frequency of safflower is relatively low. Second, our data provide evidence of the selective deletion of transgenes in specific crosses, a phenomenon that we believe is the first of this kind in an interspecific cross. Third, the traits that breeders have selected for in cultivated safflower, like seed color, high germination rates, seed weight and nonshattering seed heads, appear unlikely to provide much of a selective advantage in competitive situations in nature, as they decrease both the seed number and dispersal characteristics of the hybrids. However, the adaptive value of crop genes can be different in backcross progeny growing under different environments. Given that the genus Carthamus includes several weeds such as C. lanatus, C. leucocaulos and C. oxyacanthus, it seems sensible to avoid growing transgenic safflower in geographical areas where feral species have been reported, e.g. drier regions including California and Australia, and areas where safflower is currently being grown as an oilseed crop.

\section{Conclusion}

In this study, we report that commercial safflower will cross readily with different members of the same section (Carthamus) and several species with different chromosome numbers. All of these crosses produce F1 plants and most of them, particularly coming from wild relatives with $n=10$ and $n=12$, are viable and fertile. However, there is no evidence of hybrid vigour or other benefits provided to them.

Our analysis of some of the domestication traits that make $C$. tinctorius a commercial crop suggests that they are unlikely to provide any selective advantage when they are introgressed into wild relatives. Likewise, the transfer of a T-DNA construct from commercial safflower did not appear to have any visible effect on the hybrids.

The transgene was deleted in $21 \%$ of the hybrids from a specific cross, suggesting a negative selection mechanism against foreign DNA in some species.

\section{Methods}

Plant material

Additional File 1 provides a list of the germplasm used and the identifier number to allow the identification of the germplasm in our recent phylogenetic analysis as described in Bowles et al. [6]. The C. tinctorius parent in all crosses was the commercial safflower variety Centennial, which was homozygous for a transgene construct containing the Phosphinothricin
Acetyltransferase (pat) gene as a selectable marker (Figure 1). Seeds for this line, as well as for a nontransgenic line of Centennial, were obtained from SemBioSys Genetics Inc. (Calgary, AB, Canada). The seed lots were tested for purity and homozygosity of the transgene as described by Christianson et al. [37]. For most accessions, seeds were germinated in soil. In those cases where no germination occurred in the first attempt, $0.3 \%$ gibberellic acid $\left(\mathrm{GA}_{3}\right)$ in $\mathrm{dd}_{2} \mathrm{O}$ was added. Where possible, single seed descent was performed to reduce the level of genetic variability in the specific genotypes used in crossings. For interspecific crosses, plants were emasculated and hand pollinated, the flowers were bagged and the plants allowed to fully mature. For most crosses, three plants of each genotype were used as parents and reciprocal crosses were performed. In total, between 38 and 280 crosses were carried out for each species pair. In addition, positive control crosses (a cross with a plant of the same genotype) and negative control crosses (emasculation, but no pollination) were carried out. Once dried, seeds were harvested and stored for four to six months to allow for a break of dormancy. F1 seeds were then germinated in $\mathrm{ddH}_{2} \mathrm{O}$ and sand and, where required, $\mathrm{GA}_{3}$ was added. Parents and F1 plants were evaluated for different growth parameters and for seed set. Plants were covered with micro perforated selfing bags and allowed to self-pollinate. A number of crosses are currently being evaluated at the $\mathrm{F} 2$ and $\mathrm{BC} 1$ stage.

\section{Genotypic analysis of plants}

We used three procedures to genotype the F1 plants. Leaf tissue samples of the progeny were analyzed for the presence of the pat protein using antibody based test strips (Strategic Diagnostics Inc. 111 Pencader Drive, Newark DE). The presence and integrity of the pat gene and the T-DNA cassette was confirmed by PCR, using a combination of T-DNA and pat gene specific primers (Figure 1), as described by Christianson et al. [37]. Species-specific microsatellite markers [6, Mayerhofer $\mathrm{R}$ (unpublished results)] were used to ensure that the F1 plants were true hybrids.

Genomic DNA extractions from fresh or lyophilized leaf tissue were performed as described by Mayerhofer et al. [38]. The microsatellite loci were amplified using a modified protocol adapted from Schuelke [39]. PCR reactions contained $0.75 \mathrm{mM} \mathrm{MgCl}_{2}, 0.2 \mathrm{mM} \mathrm{dNTPs}$, $0.267 \mathrm{mM}$ reverse and M13 labeled primers, $0.067 \mathrm{mM}$ forward primer, 2.5 units of Taq DNA polymerase and 50-100 ng of template in $15 \mu$ l total volume. Thermocycling conditions were as follows: $94^{\circ} \mathrm{C}$ (5 min.); 30 cycles of $94^{\circ} \mathrm{C}$ (30sec), $56^{\circ} \mathrm{C}(45 \mathrm{sec}), 72^{\circ} \mathrm{C}(45 \mathrm{sec}) ; 9$ cycles of $94^{\circ} \mathrm{C}$ (30 sec), $53^{\circ} \mathrm{C}$ (45 sec), $72^{\circ} \mathrm{C}$ (45 sec); ending with 
$72^{\circ}$ for 10 minutes. Products from the PCR reactions were resolved on an ABI 3730 DNA Analyzer. Products were sized using Genemapper with the GeneScan 600 LIZ size standards (Applied Bioscience).

For those F1 plants where the pat protein was absent, the presence of specific components of the T-DNA cassette was determined. Figure 1 illustrates the key components of the T-DNA construct and the specific primers that were used to evaluate the F1 progeny.

Amplification of the T-DNA right border/plant DNA junction:

RB primer 5'-TATCCGCTCACAATTCCACAC-3'

RGS primer 5'-GGCAAGCCAAGCTATATCGTGA-

CAAG-3'.

Amplification of the T-DNA left border/plant DNA junction:

LB primer 5'-TAAATTTGTAGGGATATCGTG-3'.

LGS primer 5'-CAAGTGGCTTTCTTTGTAAG-3'

Amplification of the pat gene:

JCH5, 5'-GATCTGGGTAACTGGTCTAACTGG-3'

JCH6, 5'-GTTGCAAGATAGATACCCTTGGTT-3'.

Each PCR reaction was carried out in $25 \mu \mathrm{l}$ with $5 \mu \mathrm{l}$ Q-solution (Qiagen), $2.5 \mu \mathrm{l} 10 \times$ PCR buffer, $3 \mathrm{mM}$ $\mathrm{MgCl}_{2}, 0.5 \mathrm{mM}$ dNTPs, $0.5 \mathrm{mM}$ of each primer, $40 \mathrm{ng}$ of template and 2.5 units of Qiagen Taq polymerase. The cycle parameters were $95^{\circ} \mathrm{C}(10 \mathrm{~min})$, followed by 35 cycles of $95^{\circ} \mathrm{C}(20 \mathrm{sec}), 59^{\circ} \mathrm{C}(30 \mathrm{sec})$ and $72^{\circ} \mathrm{C}(45$ sec), with a final elongation step of 5 minutes at $72^{\circ} \mathrm{C}$.

\section{Additional material}

Additional File 1: List of germplasm used in study. Accessions in bold were used in crosses

\begin{abstract}
Acknowledgements
This work was supported in part by SemBioSys Genetics Inc., the Alberta Value Added Corporation (AVAC Ltd.) and a NSERC CRD to AGG. We would also like to thank the Molecular Biology Facilities, University of Alberta, for their support.
\end{abstract}

\section{Author details}

'Department of Biological Sciences, University of Alberta, Edmonton, AB, Canada, T6G 2E9. ²Department of Agricultural, Food, and Nutritional Science, University of Alberta, Edmonton, Alberta, T6G 2P5, Canada.

\section{Authors' contributions}

AGG conceived the investigation and wrote the paper with assistance from MM and RM. MM and DT performed the crosses and analyzed the plant material. RM carried out the microsatellite assays of the F1 hybrids. All authors have read and approved the final manuscript.

Received: 8 July 2009 Accepted: 14 March 2011

Published: 14 March 2011

\section{References}

1. Moloney MM: Seeds as repositories of recombinant proteins in molecular farming. Korean Journal of Plant Tissue Culture 2000, 27:283-297.
2. Estilai A, Knowles PF: Cytogenetic studies of Carthamus divaricatus with eleven pairs of chromosomes and its relationship to other Carthamus species (Compositae). American Journal of Botany 1976, 63:771-782.

3. Lopez-Gonzalez G: Acerca del la classificacion natural del genero Carthamus L., s.l. Anales del Jardin Botanico de Madrid 1989, 47:11-34.

4. Vilatersana RT, Garnatje T, Susanna A, Garcia-Jacas N: Taxonomic problems in Carthamus (Asteraceae): RAPD markers and sectional classification. Botanical Journal of the Linnean Society 2005, 147:375-383.

5. McPherson MA, Good AG, Keith A, Topinka C, Hall LM: Theoretical hybridization potential of transgenic safflower (Carthamus tinctorius L.) with weedy relatives in the New World. Canadian Journal of Plant Science 2004, 84:923-934.

6. Bowles V, Hall J, Good AG: Creation of microsatellite markers for investigation of relationships among closely related Carthamus species. 7th International Safflower Conference, Wagga Wagga, NSW, Australia 2008.

7. Chapman MA, Burke JM: DNA sequence diversity and the origin of cultivated safflower (Carthamus tinctorius L.; Asteraceae). BMC Plant Biology 2007, 7:60.

8. Rieseberg LH: Homology among RAPD fragments in interspecific comparisons. Molecular Ecology 1996, 5:99-105.

9. Smith JR: Safflower. Champaign, IL., AOCS Press; 1996.

10. Peirce JR: Morphological and phenological variation in three populations of saffron thistle (Carthamus lanatus L.) from Western Australia. Australian Journal of Agricultural Research 1990, 41:1193-1201.

11. Ayres L: Weed it and Reap. In CRC Weed Management Systems Newsletter. Volume 7. CRC Weed Management Systems, Adelaide, Australia; 1997.

12. Canadian Food Inspection Agency: Invasive Alien Plants in Canada. 2008 [http://www.inspection.gc.ca/english/plaveg/invenv/techrpt/summrese. shtml].

13. Ashri A, Knowles PF: Cytogenetics of safflower (Carthamus L.) species and their hybrids. Agronomy Journal 1960, 52:11-17.

14. Schank SC, Knowles PF: Cytogenetics of hybrids of Carthamus species (Compositae) with ten pairs of chromosomes. American Journal of Botany 1964, 51:1093-1102.

15. Vilatersana R, Brysting AK, Brochmann C: Molecular evidence for hybrid origins of the invasive polyploids Carthamus creticus and C. turkestanicus (Cardueae, Asteraceae). Molecular Phylogenetics and Evolution 2007, 44:610-621.

16. Barton $\mathrm{NH}$ : The role of hybridization in evolution. Molecular Evolution 2001, 10:551-568.

17. Ellstrand NC, Prentice HC, Hancock JF: Gene flow and introgression from domesticated plants into their wild relatives. Annual Review of Ecology and Systematics 1999, 30:539-563.

18. Basu C, Halfhill MD, Mueller TC, Steward CN: Weed genomics: new tools to understand weed biology. Trends in Plant Science 2004, 9:391-398.

19. Baker HG: The evolution of weeds. Annual Review of Ecology and Systematics 1974, 5:1-24.

20. Boudry $P$, Mörchen $M$, Saumitou-Laprade $P$, Vernet $P$, Van Dijk $H$ : The origin and evolution of weed beets: consequences for the breeding and release of herbicide-resistant transgenic sugar beets. Theoretical and Applied Genetics 1993, 87:421-428.

21. Hall L, Topinka K, Huffman J, Davis L, Good A: Pollen flow between herbicide-resistant Brassica napus is the cause of multiple resistant $\mathrm{B}$. napus volunteers. Weed Science 2000, 48:688-694.

22. Dukes JS, Mooney HA: Does global change increase the success of biological invaders? Trends in Ecology and Evolution 1999, 14:135-140.

23. Dajue L, Mündel HH: Safflower. Carthamus tinctorius L. Promoting the conservation and use of underutilized and neglected crops. Institute of Plant Genetics and Crop Plant Research, Gatersleben/International Plant Genetic Resources Institute, Rome, Italy; 19967.

24. Imrie BC, Knowles PF: Genetic studies of self-incompatibility in Carthamus flavescens Spreng. Crop Science 1971, 11:6-9.

25. Knowles PF, Ashri A: Safflower: Carthamus tinctorius (Compositae). In Evolution of crop plants.. 2 edition. Edited by: Smartt J, Simmonds NW. Harlow Publisher, New York; 1995:47-50.

26. Hauser TP, Jørgensen RB, Østergård $H$ : Fitness of backcross and $F_{2}$ hybrids between weedy Brassica rapa and oilseed rape (B. napus). Heredity 1998, 81:436-443.

27. Hauser TP, Shaw RG, Østergård $H$ : Fitness of $F_{1}$ hybrids between weedy Brassica rapa and oilseed rape (B. napus). Heredity 1998, 81:429-435. 
28. Lexer C, Welch ME, Raymond O, Rieseberg LH: The origin of ecological divergence in Helianthus paradoxus (Asteraceae): selection on transgressive characters in a novel hybrid habitat. Evolution 2003, 57:1989-2000

29. Ashri A, Efron Y: Inheritance studies with fertile interspecific hybrids of three Carthamus L. species. Crop Science 1964, 4:510-514.

30. Imrie BC, Knowles PF: Inheritance studies in interspecific hybrids between Carthamus flavescens and C. tinctorius. Crop Science 1970, 10:349-352.

31. Edmands S: Between a rock and a hard place: evaluating the relative risks of inbreeding and outbreeding for conservation and management. Molecular Ecology 2006, 16:463-475.

32. Zimmerman LH: Variation and selection for preharvest seed dormancy in safflower. Crop Science 1972, 12:33-34.

33. Kotecha A, Zimmerman LH: Genetics of seed dormancy and its association with other traits in safflower. Crop Science 1978, 18:1003-1007.

34. Chapman MA, Burke JM: Letting the gene out of the bottle: the population genetics of genetically modified crops. New Phytologist 2006 170:429-443.

35. Haygood R, Ives AR, Andow DA: Consequences of recurrent gene flow from crops to wild relatives. Proc $R$ Soc Lond B 2003, 270:1879-1886.

36. Hill R: Conceptualizing risk assessment methodology for genetically modified organisms. Enviromental Biosafety Research 2005, 4:67-70.

37. Christianson J, McPherson M, Topinka D, Hall L, Good AG: Detecting and quantifying the adventitious presence of transgenic seeds in safflower, Carthamus tinctorius L. Journal of Agricultural and Food Chemistry 2008, 56:5506-5513

38. Mayerhofer R, Wilde K, Mayerhofer M, Lydiate D, Bansal VK, Good AG, Parkin IAP: Complexities of chromosome landing in a highly duplicated genome: Toward map-based cloning of a gene controlling blackleg resistance in Brassica napus. Genetics 2005, 171:1977-1988.

39. Schuelke M: An economic method for the fluorescent labeling of PCR fragments. Nature Biotechnology 2000, 18:233-234.

doi:10.1186/1471-2229-11-47

Cite this article as: Mayerhofer et al:: Introgression potential between safflower (Carthamus tinctorius) and wild relatives of the genus Carthamus. BMC Plant Biology 2011 11:47.

\section{Submit your next manuscript to BioMed Central} and take full advantage of:

- Convenient online submission

- Thorough peer review

- No space constraints or color figure charges

- Immediate publication on acceptance

- Inclusion in PubMed, CAS, Scopus and Google Scholar

- Research which is freely available for redistribution

Submit your manuscript at www.biomedcentral.com/submit
Biomed Central 